\title{
A OBRIGAÇÃO ALIMENTAR EM FAVOR DA PESSOA IDOSA: UMA ANÁLISE DA SOLIDARIEDADE PASSIVA COMO CONSTRUÇÃO DE UMA NOVA DIGNIDADE
}

\section{Merilany Gelsleichter ${ }^{1}$}

Resumo: O presente artigo visa à apuração da verdadeira natureza da obrigação alimentar em favor do idoso, no que se refere ao atributo da solidariedade passiva, em face das antinomias entre a doutrina do direito obrigacional e do direito de família em relação à regra do Estatuto do Idoso a esse respeito.

Palavras-chave: solidariedade passiva. obrigação alimentar. Estatuto do Idoso.

\section{INTRODUÇÃO}

Este estudo tem por objetivo determinar a natureza da obrigação alimentar em favor do idoso no aspecto da solidariedade passiva. Em razão de o Código Civil de 2002 defini-la como uma

1 Aluna da Escola Superior da Magistratura do Estado de Santa Catarina (ESMESC). Advogada. Especialista em Direito Material e Processual Civil (CESUSC) em convênio com a ESMESC e em Direito do Trabalho e Processual do Trabalho (UNIVALI) em convênio com a Associação dos Magistrados do Trabalho da $12^{\mathrm{a}}$ Região (AMATRA 12). Bacharel em Direito pela Universidade do Vale do Itajaí (UNIVALI) e licenciada em Letras/Inglês pela Universidade Federal de Santa Catarina (UFSC). E-mail: merilany@hotmail.com 
pluralidade de devedores responsável pelo adimplemento total da obrigação reversível ao mesmo credor, problematiza-se a acuidade da classificação adotada pelo art. 12 do Estatuto do Idoso, Lei $10.741 / 2003$, por ser a prestação fixada com base na possibilidade do alimentante. À luz do princípio da dignidade da pessoa humana e da efetividade do processo, concluiu-se pela aplicação da regra do Estatuto nas demandas alimentares em favor de idoso, porquanto mais específica e adequada à doutrina da proteção integral, a despeito dos aparentes conflitos entre esta e as normas atinentes à intervenção de terceiros, instituto de direito processual.

\section{A INTEGRIDADE DO IDOSO COMO PRECEITO CONSTITUCIONAL}

\subsection{Considerações sobre a Teoria das Gerações de Direitos: os "Novos Direitos"}

O termo "novos direitos" designa uma nova categoria de direitos fundamentais. É amplamente utilizado pela doutrina sob a denominação de direitos transindividuais, ou metaindividuais. Empregar-se-á aqui o de procedência latina, transindividual, ao teor das lições Mazzilli (2002).

Bobbio (2004) opta por dividir os direitos em cinco categorias, pautado na idéia de que a conquista de cada uma delas precedeu a seguinte. Em razão da evolução gradativa de conquistas, que culminariam na insurgência pelo reconhecimento de novos direitos, foi consolidada a expressão de "gerações de direitos". No processo de positivação de direitos, destacam-se a Declaração dos Direitos do Homem e do Cidadão, a Declaração da Virgínia e de Independência dos Estados Unidos.

Os "novos direitos", tais como aqui representados, equivalem à terceira geração de direitos da teoria difundida por Bobbio. Em sua classificação, os direitos civis e políticos correspondem à primeira geração de direitos, ao passo que os direitos sociais, nos seus primeiros rudimentos de instrução contra o analfabetismo e assistência por invalidez e velhice, equivalem à 
segunda geração. Dessas teria emergido a categoria a seguir analisada, que, segundo o próprio autor, ainda é heterogênea e vaga.

Optou-se por substituir o termo geração, presente na obra de Bobbio, pelo correlato 'dimensão'. Foi acolhido o posicionamento de Wolkmer (2003), no sentido de que a expressão "geração de direitos" leva o estudioso a crer elas se sucedem pura e simplesmente e deixam de existir. Tal interpretação não se coaduna com a necessidade de tutela das primeiras garantias conquistadas, que são, ainda, usualmente desrespeitadas. Para o autor, as dimensões de direitos precedentes continuam sendo aplicadas e seguem evoluindo de acordo com seu objeto. $\mathrm{O}$ rol de direitos civis e políticos aumenta e se aperfeiçoa à proporção que a sociedade e a Ciência do Direito evoluem.

Pela natureza transindividual, isto é, por serem, via de regra, indivisíveis, os direitos de terceira geração têm características peculiares no que tange à sua aplicação. $\mathrm{O}$ cidadão titular de direitos dessa natureza assim o é por uma condição pessoal, que faz merecer tutela específica (MAZZILLI, 2002).

Há bens jurídicos cuja titularidade é impossível determinar. Tomemos como exemplo o meio ambiente saudável e equilibrado. $\mathrm{O}$ interesse pela preservação deste bens, conforme se extrai da lei, é de todos os nascidos e aqueles que estão por nascer. Do direito social à saúde, nasce o direito ao meio ambiente saudável, que é, entretanto, impossível de segmentar. A qualidade do ar, das águas, da vegetação e da fauna compromete não apenas a geração que dela se utiliza no momento, mas ainda as subseqüentes (MAZZILLI, 2002).

Da ampliação do que se entendia por cidadania e, por conseguinte, da criação de novos bens jurídicos, constatou-se a carência de regulamentação diferenciada para determinados segmentos sociais. Exsurgem daí iniciativas estatais sensíveis a peculiaridades como etnia, idade e necessidades especiais. $\bigcirc$ fim pretendido por essas ações não foi discriminá-los, mas sim thes conferir compensações por fragilidades e carências. Conforme explorado, é nesse limiar que se encontra a fundamentação das 
normas protetivas, sob o fundamento da regra da proporcionalidade em respeito à isonomia constitucional.

A totalidade das crianças brasileiras é um bem difuso, por exemplo, pois estas compõe um conjunto indeterminável de sujeitos. A inobservância das normas que lhe são destinadas lesa, por assim dizer, o interesse de toda a sociedade. Este interesse decorre de sua hipossuficiência, porque frágeis do ponto de vista físico e emocional. São seres em desenvolvimento, que carecem de assistência integral (MAZZILLI, 2002).

Além dos direitos difusos (art. 81, I, do CDC), existe, ainda, a previsão acerca da pluralidade de sujeitos de direito de uma mesma relação processual em duas diferentes maneiras, a saber, os direitos coletivos e individuais homogêneos. Em síntese, a diferença entre eles se pauta no fato de que, entre os primeiros, existe uma relação jurídica anterior ao acontecimento danoso ao grupo, como por exemplo, a existência formal de um sindicato, ou associação. Nos Direitos Individuais Homogêneos, não há elo entre os sujeitos lesados. A ameaça ou o dano acontecem individualmente, em decorrência de uma causa comum a um grupo de pessoas determinável, ou indeterminável, como no caso dos consumidores de um determinado produto veiculado com defeito pelo produtor, por exemplo (MAZZILLI 2002).

Ainda segundo a teoria da era dos direitos de Bobbio, conforme se pode observar da leitura de Wolkmer (2003), mais duas dimensões de direitos estão se desenvolvendo. Novamente, para o alcance dos propósitos aqui pretendidos, basta sintetizar que se referem às inovações da biotecnologia e da engenharia genética, dos quais tiveram gênese os termos "Biodireito" e do Direito e Informática, dadas as inovações tecnológicas significativas ocorridas após o surgimento da Internet. Tanto a quarta quanto a quinta dimensão de direitos contemplam direitos tipicamente individuais, sociais e transindividuais.

As novas dimensões de direito têm origem, conforme Bobbio (2004) expunha, de modificações na organização das sociedades contemporâneas e da conseguinte evolução do 
conceito de cidadania. $\mathrm{O}$ reconhecimento de direitos por parte do Estado em relação aos seus cidadãos foi um processo historicamente construído. Não se pautou na bem-aventurança dos governantes, mas na luta de classes, que estavam em desvantagem política e econômica. Em todas as formas de organização humana, os grupos menos poderosos incitam-se à busca de melhorias, utilizando-se das estratégias de que dispõe à época.

Os idosos, assim como as crianças, podem, em verdade, ser protegidos por meio da tutela individual. No entanto, por ser o seu bem estar concebido como interesse de toda a sociedade, fazem por merecer todas as benesses da tutela coletiva, por seus consecutários desdobramentos legais.

\subsection{0 envelhecimento compreendido como bem jurídico na Constituição Federal de 1988: o Princípio da Dignidade da Pessoa Humana e os alimentos em favor do idoso}

A Constituição Federal de 1988 adotou princípios norteadores da interpretação das demais normas de maneira explícita e implícita. Para compreender a tutela dos direitos do idoso como um todo, torna-se imperiosa a análise da Dignidade da Pessoa Humana, que vai orientar desde a forma de organização do Estado à implementação de políticas públicas.

Para manter a integridade do sistema jurídico, tal qual pensado - em prestígio à Supremacia da Constituição - é imprescindível, via de regra, que as normas produzidas pelo Estado, na sua Função Legislativa, coadunem-se com os mandamentos positivados em $1988^{2}$ (PAULO, 2006). Desta forma, a análise do princípio declinado, bem como dos dispositivos que tratam do idoso, é medida que se impõe para a compreensão do Microssistema Legislativo de 2003 (Lei 10.741/03).

Cumpre delinear que o conceito de dignidade admite subjetivismos, pois se relaciona a determinadas peculiaridades

2 Ressalvadas as Emendas Constitucionais, que por seu quorum de aprovação específico, é meio hábil para a alteração do Texto Maior (art. 60 da CF/88). 
da pessoa humana como idade, aptidão física, que devem ser respeitadas em todas as relações interpessoais, inclusive nas vivenciadas no contexto familiar (DELGADO, 2006).

Neste particular, imprime-se especial atenção ao afeto. Por meio de temas que permeiam o Direito, faz-se possível delimitar como o afeto opera na psique do sujeito e as consequências decorrentes da ausência deste. Groeninga (2006) retoma ensinamentos da psicanálise em relação à constituição do sujeito, na perspectiva de que a identidade "(idem + entidade)" decorre das experiências vivenciadas com os pais.

Infere-se que a falta de afeto também atinge aos idosos. Por experimentarem, em regra, um decréscimo significativo na produtividade de suas atividades, ficam suscetíveis a uma etapa de grande instabilidade emocional. Por esta razão é que o legislador define o convívio familiar como um direito, dispondo categoricamente, por exemplo, via Constituição, que caberá à família o amparo para com a pessoa idosa, em conjunto com o Estado e a sociedade (art. 230 da CF/88).

Ao utilizar-se das expressões "convívio social" e, na sequência, "amparo", parece que a Carta Cidadã estende o conceito de dignidade para além de condições básicas de alimentação e higiene, ou de saúde, lazer. Relacionou-o também com o convívio familiar, a fim de que o idoso possa receber e dar afeto.

A Constituição Federal de 1988 fez menção expressa à Dignidade da Pessoa Humana, já em seu $1^{\circ}$ artigo. A República Federativa do Brasil constitui-se em Estado Democrático de Direito, na dicção do caput, e, entre seus fundamentos (no inciso III) ela se encontra. A despeito de as normas constitucionais não apresentarem hierarquia entre si, em razão do Princípio da Unidade da Constituição, não parece neutra a opção do constituinte em insculpir, na Carta, seu interesse por uma ordem constitucional comprometida com a pessoa humana, com o sujeito (PAULO, 2006).

O desígnio de regulamentação específica sobre o envelhecer não se associa ao de segmentar o exercício dos direitos fundamentais a partir de etapas de vida, mas sim de se ater às 
peculiaridades com o fim de proporcionar políticas públicas mais direcionadas e, logo, eficazes para este público. Dessa forma, apesar de o art. $3^{\circ} \mathrm{da} \mathrm{CF} / 88$ esclarecer que a idade não interfere no gozo de quaisquer direitos, o texto constitucional preceitua regras específicas para o idoso.

A Constituição Federal de 1988 adota o ideal de coletivização de direitos, dispondo em seu art. 230, caput, proteção característica de um bem difuso, pois não onera somente o Estado, mas também a família e a sociedade no amparo da pessoa idosa. Criou um bem jurídico e a necessidade de reconstruir meios passíveis de tutelá-los. Presuminda de interesse de toda a sociedade a preservação da dignidade do idoso, o polo ativo potencial de uma lide não se limitará ao idoso isoladamente, compreenderá os co-legitimados para a defesa de direitos coletivos lato sensu (MAZZILLI, 2002).

No que se refere aos direitos de alimentos, a Constituição ainda exorta normas mais específicas do que a dos artigos anteriormente mencionados, tanto na prestação devida pelo Estado, como quando devida pela família. Quanto às que disciplinam a prestação pelo Poder Público, serão aplicadas ao idoso que satisfaça determinados requisitos legais. No que se refere às prestações devidas pela própria família ao idoso, a CF/88 dispõe, em seu art. 229, que os filhos maiores têm o dever de ajudar a amparar os pais na velhice, carência, ou enfermidade. Tal dispositivo contribuiu para a produção subsequente de normas infraconstitucionais em favor dos pais.

A Constituição Federal de 1988 não se refere especificamente à solidariedade da obrigação, esclarece ao intérprete apenas que a família tem o dever de alimentar o idoso e, da mesma forma, o Estado, conforme outras normas de cunho assistencial aludidas. As normas constitucionais, em decorrência da supremacia já explorada, vão direcionar a produção infraconstitucional e, ainda, servirão de fundamento para a preservação da dignidade do idoso - sem o pretexto de a falta de regulamentação obstaculizar sua aplicação. 


\section{A REGULAMENTAÇÃO INFRACONSTITUCIONAL DOS ALIMENTOS PARA A TERCEIRA IDADE}

\subsection{0 dever jurídico entre ascendentes e descen- dentes no CC/2002}

Dentre os conceitos do Direito Obrigacional a serem revisitados, optou-se pela estrutura das obrigações. São compostas de três elementos essenciais, a saber, subjetivo ou pessoal (sujeitos da obrigação), objetivo ou imaterial (objeto sobre o que recai a obrigação) e o elemento ideal, também chamado de imaterial, ou ainda, espiritual (vínculo jurídico). $O$ vínculo jurídico é traduzido na sujeitação patrimonial. Reunidos todos os elementos, será a obrigação dita perfeita (GAMA da, 2008).

Dentro da concepção doutrinária dualista, o vínculo jurídico é decomposto em dois novos fatores: débito e responsabilidade. O débito consiste no dever de prestar e a responsabilidade é a faculdade de o credor, diante do inadimplemento da obrigação, atingir o patrimônio do devedor para ver satisfeito seu crédito. Por isso, fazem-se afirmações no sentido de que a responsabilidade compõe a obrigação em estado potencial, pois só será reconhecida quando aquela não for adimplida (GAMA da, 2008).

Para uma obrigação ser exigível judicialmente, os dois fatores deverão estar presentes, via de regra ${ }^{3}$. Não havendo responsabilidade, ainda que constituído o débito, deflagrar-se-á uma obrigação juridicamente inexigivel, denominada obrigação natural (GAMA da, 2008). Em que pese a não exigibilidade jurídica, nada impede que o devedor proceda ao adimplemento, pois aquela não equivale à quitação, sob o ponto de vista moral.

Admite-se obrigação alimentar como perfeita e juridicamente exigivel porque todos os elementos estão presentes: os subjetivos, alimentantes e alimentados; o objetivo, a prestação em dinheiro ou o que o equivalha; e o vínculo jurídico, o estado de sujeição patrimonial. Da mesma forma, presentes o débito e

3 Resguardam-se as hipóteses de garantia real dada por terceiro, na medida em que poderá ser compelido a pagar, apesar de não ter concorrido diretamente para a aquisição da dívida. Em outras palavras, haverá a responsabilidade sem o débito (GAMA da, 2008). 
a responsabilidade, convalida-se o dever moral em obrigação, no sentido jurídico do termo (GAMA da, 2008).

A necessidade de regulamentar os arts. 229 e 230 da CF/88 culminou nas disposições do Código Civil de 2002 a seguir abordadas, apesar de se prestar preponderantemente à tutela de direitos privados, em prestígio ao fundamento republicano da dignidade da pessoa humana.

O art. 1.696 do CC expressamente preceitua a regra da reciprocidade do direito à prestação entre pais e filhos, e estende o estado de sujeição dos filhos em relação aos pais. O artigo 1.697 do CC determina que, em não havendo ascendente capaz de satisfazer a prestação, recairá esta ao descendente. A despeito de a regra não fazer menção expressa à terceira idade, pois não há critério de idade estabelecido no dispositivo, é aplicável a todos que têm descendentes, o que permite a subsunção do idoso à posição de alimentado e de filho à de descendente alimentante (RIZZARDO, 2008).

Sobre o dever de alimentar decorrente da ordem de vocação hereditária, Dias (2007) é favorável à prestação de alimentos dos netos em benefício aos avós, uma vez que àqueles é lícito demandar contra estes, na hipótese de o pai não os puder prestar. Aplicada a regra de reciprocidade, não subsistiriam razões para a proibição do litígio em face dos netos, se respeitada a ordem de vocação hereditária primeiramente, isto é, desde que todos os esforços para atingir o patrimônio dos pais tenham sido inexitosamente empreendidos.

É, porém, no art. 1.698 que se encontram as regras aqui reputadas de valor superior ao aprofundamento dos alimentos para ascendentes. Ao final do dispositivo, o legislador fez constar que, na existência de mais de um obrigado à prestação de alimentos, todos eles devem concorrer na proporção dos respectivos recursos. Ainda, autoriza a inclusão de todos os devedores na lide. Emprega, entretanto, a expressão "poderão ser incluídos”, cabendo ao intérprete buscar alcançar seu sentido.

Para que a obrigação alimentar seja exequível, deve ser observada a leitura do art.1.695 do CC/02. Resumem-se em 
três os pressupostos da prestação alimentar: o vínculo de parentesco, a necessidade do alimentado e a possibilidade do alimentante, de forma a conferir legitimidade à pretensão.

A concorrência dos pressupostos recebe a nomenclatura de binômio necessidade-possibilidade, utilizado tanto pela doutrina quanto pela jurisprudência. Respalda-se na regra expressa no $\$ 1^{\circ}$ do art.1.694 do CC. Ao fazer referência ao dispositivo, Dias (2007) faz constar a imprescindibilidade do princípio da proporcionalidade como vetor na fixação de alimentos, relatando a utilização, cada vez mais frequente, do termo trinômio proporcionalidade-possibilidade-necessidade.

Havendo modificação da relação fática do alimentante/ alimentado, surgirá o interesse de agir para a propositura de eventual Ação Revisional de Alimentos. A doutrina nomeia tal característica como variabilidade da obrigação alimentar, que foi observada pelo Código Civil de 2002, no art. 1.699, correspondente ao art. 401 do Código Civil de 1916.

\subsection{Poder Público como prestador de alimentos nas Leis 8.742/93 (Lei Orgânica da Assistência Social - LOAS); 8.842/94 (Política Nacional do Idoso - PNI) e 10.741 (Estatuto do Idoso)}

Além do Código Civil, outras iniciativas para regulamentar a matéria ocorreram. Após a promulgação da Constituição, dispôs a Lei Orgânica da Assistência Social (LOAS - nº 8742/93) normas específicas de prestação assistencial em favor do idoso.

A LOAS utiliza o conceito de "mínimos existenciais" para o desencadeamento de auxílio governamental. Destina seção específica ao Benefício da Prestação Continuada (BPC), a ser requerido por idoso, ou deficiente, cujo grupo familiar possua renda mensal per capita inferior a $1 / 4$ de salário mínimo. Exemplificando, um pai de família idoso que aufira renda de um salário mínimo, com três dependentes no grupo familiar, não fará jus ao recebimento do benefício em questão, pois a renda per capita será superior a 1/4 de salário mínimo. Desta forma, verifica-se que a política assistencial 
está dissociada dos demais preceitos constitucionais já abordados anteriormente, como o da Dignidade da Pessoa Humana e, quiçá, o do Estado Democrático de Direito. Os "mínimos essenciais" estão abaixo do mínimo, estão há pelo menos $1 / 4$ dele.

Muitos beneficiários irresignados propuseram demandas contra o INSS e obtiveram resultados favoráveis em $1^{\circ}$ grau, com base na inconstitucionalidade do critério por inobservância da dignidade da pessoa humana. O Supremo Tribunal Federal julgou, por maioria, improcedente a Ação Direta de Inconstitucionalidade $n^{\circ}$ 1.232-1, ajuizada pelo Procurador Geral da República por ter o parâmetro do benefício sido validamente estabelecido na lei, conforme autorizado pela própria Consituição.

Em decorrência da reiterada inobservância do teor da decisão proferida em sede de controle de constitucionalidade pelos juízes de $1^{\circ}$ grau, interpôs a autarquia federal Reclamação no STF. O julgamento perpetrado pela Ministra Ellen Gracie acatou a tese do reclamante, fazendo cessar o cabimento de novas discussões acerca do dispositivo (PONTES, 2008).

$\mathrm{O}$ art. 20 da LOAS considera idoso, para efeitos de recebimento do benefício, a pessoa com idade igual, ou superior a 70 anos. Por não existir no ordenamento, até a promulgação da norma, disposição objetiva para a subsunção de um indivíduo à categoria de idoso, restou o questionamento se todas as medidas protetivas direcionadas ao idoso considerariam o critério dos 70 anos, ou se estes deveriam ser comprovados apenas para o recebimento do Benefício da Prestação Continuada (BPC).

A questão ficou ainda mais tumultuada com a promulgação da Lei 8.842/94, que dispõe sobre a política nacional do idoso, cria o Conselho Nacional do Idoso e dá outras providências. Isto porque esta lei, que ficou conhecida como Política Nacional do Idoso, em seu art. $2^{\circ}$, preceitua expressamente que será considerada idosa a pessoa maior de sessenta anos de idade. O legislador fez constar que o idoso merecerá proteção especial a partir de 60 anos, mas a dúvida subsistia em relação ao BPC. Despontava a inquietude na escolha do critério mais adequado para a interpretação das normas conflitantes. 
Com fulcro no critério cronológico, os 70 anos seriam transmutados para 60. Subsistindo a premissa de que o tema tratado nas duas leis coincidia, porquanto dispunham sobre o idoso incluída a assistência social em benefício dele, derrogada estaria a lei anterior. Adotado o critério da especificidade, prestigiar-se-ia a LOAS, se o intérprete entendesse mais específico o diploma sobre a matéria assistencial, ou a Política Nacional do Idoso (PNI), se a assistência fosse entendida como instrumento para o bem estar do idoso, contemplado, nesta última lei, por inteiro.

A controvérsia parecia ter sido resolvida com a promulgação da Lei 9.720/98, que alterou o critério para a obtenção do benefício para 67 anos. Tudo levou a crer, na época, que a pessoa idosa merecia amparo específico a partir dos 60 anos, podendo requerer o benefício assistencial, porém, somente com 67 completos.

Vale lembrar que, além do plano assistencial, o Estado é incumbido de uma série de atos para integrar o idoso ao convívio familiar e social, dentro da perspectiva de dignidade da pessoa humana trabalhada. O legislador demonstra necessário esclarecer o envelhecimento às demais parcelas da sociedade, preocupação que faz muito sentido, diante do aumento significativo da expectativa de vida no país (RAMOS, 2003).

Já no que se refere à Lei 10.741/03, Estatuto do Idoso, optou-se por destacar os arts. 9॰, 11, 12 e 14, dispostos no Capítulo III, intitulado Dos Alimentos, com exceção do primeiro dispositivo, analisado ao final.

O Estatuto (art. 11) prevê que os alimentos serão prestados na forma da lei civil e, para tanto, são aplicáveis não apenas a CF/88, como também o Código Civil de 2002, nos seus dispositivos analisados, bem como na Lei no 5.478/68 (Lei dos Alimentos). A solidariedade da obrigação alimentar, introduzida textualmente pelo art. 12 do Estatuto do Idoso, será abordada posteriormente. $\mathrm{O}$ que cabe destacar é que o dispositivo autoriza ao idoso optar por demandar quaisquer dos potenciais devedores elencados no conjunto de leis já mencionado.

$\mathrm{O}$ art. 14 faz referência ao âmbito da assistência social, na hipótese de os familiares não possuírem condições de prover o 
sustento do idoso. Será o benefício de 1 salário mínimo, nos termos da LOAS, como reiterado no art. 34 do próprio Estatuto. Ocorre que o dispositivo altera a regra anterior de 67 anos para a idade de 65 , constituindo o marco definitivo utilizado pelo INSS para a concessão do benefício atualmente.

Novamente, defende-se que a regra destoa do próprio entendimento da lei acerca do que é ser idoso, pois o art. $1^{\circ}$ do Estatuto dispõe que ele regulará os direitos assegurados às pessoas com idade igual ou superior a 60 anos. Pontes discorda da exclusão das pessoas com idade entre 60 e 65 anos do percebimento do benefício, por intermédio da norma específica do art. 34. Aduz que a Constituição faz referência tão somente à pessoa idosa e, para tanto, não classifica a terceira idade em subcategorias de faixasetárias. Entretanto, a discussão já fora pacificada pela Suprema Corte, consoante colocado, porquanto à lei ordinária cabia regulamentar o texto constitucional (PONTES, 2008).

Por fim, o art. $9^{\circ}$ estipula regras mais amplas do que a prestação alimentar assistencial. $O$ dispositivo atribui expressamente ao Estado o encargo de efetivar políticas sociais públicas como premissa para o envelhecimento saudável, que pressupõem uma atuação estatal coordenadora das ações governamentais e da sociedade civil em favor da observância dos mandamentos constitucionais. É uma atividade complexa comum ao Executivo, Legislativo e Judiciário, dependente de sua harmonia e integração, bem como da participação da sociedade civil organizada, a fim de eleger meios idôneos para realizá-las (MEDEIROS de, 2008).

\section{A APLICAÇÃO DO PRINCÍPIO DA INSTRUMEN- TALIDADE DO PROCESSO NA EFETIVAÇÃO DA DIGNIDADE DO IDOSO}

\section{1 $O$ instituto da solidariedade no Direito Obri- gacional e na diç̧ão do Estatuto do Idoso: impli- cações processuais}

Com respaldo na legislação civil, é possível afirmar que a solidariedade consiste em atributo da relação jurídica, por cuja 
satisfação se vincula uma pluralidade de sujeitos na parte ativa, ou passiva. Para o alcance dos objetivos pretendidos, reveste-se de imprescindibilidade a análise da solidariedade passiva, que autoriza o exaurimento do patrimônio de duas ou mais pessoas, em conjunto ou separadamente, até a satisfação integral do crédito.

A exoneração da obrigação só é possível mediante quitação. Na hipótese de adimplemento parcial, todos continuarão responsáveis pelo valor remanescente. Restará àquele que efetuou o pagamento de quantia excedente à sua quota-parte, quando divisível a obrigação, exercer o direito de regresso em face do inadimplente (GAMA da, 2008).

A ausência de um devedor no polo passivo da demanda não acarretará renúncia à quota por ele devida, ou da solidariedade passiva em si. O parágrafo único do art. 275 do Código Civil exclui tal possibilidade. $\mathrm{O}$ momento de fazê-lo constitui liberalidade do credor, pois the é lícito demandar em face de quem acredita reunir melhores condições de satisfazer o crédito.

Deve-se destacar a impossibilidade de presunção de solidariedade passiva na relação obrigacional, pois nenhum sujeito ver-se-á compelido a satisfazer quota-parte diversa daquela por que se obrigou, no silêncio da lei ou da vontade das partes, consoante determinação do art. 265 do Código Civil (redação idêntica ao 896 do CC de 1916).

Esta regra é demasiadamente relevante para a verificação da característica da obrigação alimentar em favor do idoso, em razão da previsão expressa do art. 12 da Lei 10.741 acerca da solidariedade. Evidentemente a previsão na lei é argumento substancial para a defesa de um posicionamento. Entretanto, é necessário transcender a afirmativa de que a obrigação pertence a dada classificação porque o legislador assim o quis, até porque este, não raramente, sofre críticas.

Devem ser analisadas as disposições legais, em verdade, mas, de igual importância são os subsídios doutrinários, que visam a recuperar o alcance do instituto em si, desde a sua concepção, permitindo aferir sua aplicabilidade atual, diante da 
vertiginosa modificabilidade das relações obrigacionais oriundas do ambiente familiar.

Rizzardo (2008) entende pela não solidariedade dos alimentos em linhas gerais. Para ele, a coincidência de alimentantes no mesmo plano (grau), como no caso de vários filhos em benefício de um genitor comum, não decorre da solidariedade. Quando o alimentado for pessoa idosa, todavia, mostra-se favorável à solidariedade.

Reconhece a preponderância do Estatuto de 2003 em decorrência das peculiaridades do segmento do idoso, não apenas pela textualidade do art. 12 da Lei 10.741/03. Entende que, se o art. $3^{\circ}$ da lei assegura celeridade no processo em razão das peculiaridades do bem jurídico, devem as regras compassar-se com o desiderato da proteção, viabilizando o acionamento judicial de apenas um dos devedores para resguardar a celeridade do processo e a integridade do idoso, se este assim o preferir .

Dias (2007, p.154) entende inviáveis as investidas do intérprete contra a solidariedade, fundadas na divisibilidade da obrigação. Para a autora, a divisibilidade dos alimentos "não desconfigura a natureza solidária da obrigação, que tem o intuito de não deixar desatendido quem não dispõe de condições de se manter”. Defende que a norma legal definiu a natureza do encargo alimentar como solidária em razão de o idoso merecer especial proteção do Estado, também na Função Legislativa, não apenas no campo assistencial.

Acrescenta, por fim, que a despeito da classificação dos alimentos como solidários, eles não reúnem todas as características da solidariedade. Não se pode afastar a incidência da regra da proporcionalidade no binômio "necessidade-possibilidade", ainda que quaisquer dos devedores possam ser acionados. Defende, por isso, que um devedor não poderá ser compelido à integralidade da dívida toda, se não lhe for possível ${ }^{4}$.

4 Deve-se determinar, portanto, o conceito de dívida toda: se é a quantia suficiente às necessidades do idoso na promoção de sua dignidade, ou se é o valor fixado objetivamente ao acionado. Se for a primeira opção, o alimentante poderá não responder pela dívida toda, se não puder - o que afasta a solidariedade, como propunha Dias (2007). Se for a segunda, adimplirá completamente a obrigação, satisfazendo a prestação nos termos fixados em juízo. Este tema fica sugerido para novas pesquisas. 
No que concerne à processualística envolvida na obrigação alimentar em favor do idoso, destaca-se a aplicação polêmica da intervenção de terceiros, conforme permissivo do art. 77, III, do CPC. O chamamento ao processo consiste em meio de formação de litisconsórcio passivo, por iniciativa do réu, com aplicabilidade aos devedores solidários. Tem por objetivo chamar aqueles que devem tanto, ou mais do que este, para responderem juntos. Como conseqüência, é criado um título executivo para posterior sub-rogação do réu no lugar de credor do chamado, levando-se a feito o princípio da economia processual (WAMBIER; TALAMINI; ALMEIDA de, 2008). Questiona-se, assim, a compatibilidade da inclusão de terceiros no polo passivo com a necessidade de celeridade da prestação, por a regra preceituar a solidariedade e possibilitar a demanda contra quaisquer devedores.

Primeiramente, em relação à regra do art. 1.698 do Código Civil de 2002, Didier (2009) defende que caberá a aplicação de nova modalidade de intervenção de terceiros, dita sui generis. Se não há possibilidade de direito de regresso, descabida a denunciação da lide. Se não há solidariedade, não se pode falar nem de chamamento ao processo. A expressão "chamar" para integrar a lide do art. 1.698 do CC/2002 levaria à falsa percepção de se estar diante do chamamento ao processo. $\mathrm{O}$ autor, entretanto, desencoraja tal inferência, argumentando que o dispositivo refere-se à atuação do autor e não do réu. Àquele teria sido dada a prerrogativa de processar os demais devedores. Tratar-se-ia de espécie um caso atípico de litisconsórcio passivo facultativo ulterior.

Já no que se refere à regra do Estatuto do Idoso, é o teor da sua lição (2009, p.339):

O Estatuto do Idoso (Lei Federal n. 10.741/03) inovou no tratamento da obrigação alimentar, prevendo, em seu art. 12, a solidariedade da obrigação alimentar em favor do idoso. A regra é esdrúxula e foge à tradição de a obrigação alimentar ser devida nos limites da capacidade econômica 
do devedor. Acaso a regra seja interpretada literalmente (o que não nos parece correto), é possível dizer que, na ação de alimentos cujo autor é idoso, admitem-se tanto a intervenção por provocação do demandante, ora comentada, como, também, o chamamento ao processo, em razão do vínculo de solidariedade que une o devedor- demandado e outro co-devedor, em face de quem a demanda não foi inicialmente formulada (grifos nossos).

Outor, logo, insurge-se contra a solidariedade passiva porquanto não se condenará qualquer devedor ao pagamento da dívida, ante a comprovação de impossibilidade de efetuá-lo, por inteiro, ou mesmo no equivalente à sua parte. Para ele, incabível é o chamamento ao processo porque não deflagrada a situação do art. 77, III, do CPC.

Pereira (2007) antevê prejuízo à celeridade da demanda e entende contraditórias as regras de direito material sobre a solidariedade e a intervenção de terceiros, responsável pela estrutura do polo passivo do conflito, uma vez que cabe ao credor fazer a escolha de integrá-lo, no instituto do Direito Civil.

Acatada ou refutada a tese da solidariedade, insta mencionar, por fim, que a obrigação será subsidiária em relação ao Estado. Este só poderá ser demandado para prestar alimentos, quando a família não o puder fazer. Conclui-se pela subsidiariedade em função do texto da Lei Orgânica da Assistência Social (INDALENNCIO, 2008).

\subsection{Princípio da Instrumentalidade como garantidor da eficácia das decisões judiciais: a simbiose entre o Princípio da Efetividade do Processo e o da Dignidade da Pessoa Humana}

A principiologia adotada pelo ordenamento jurídico brasileiro desempenha importante papel na função do intérprete. Já se atribuiu a eles papel de coadjuvantes nos fazeres hermenêuticos. Porém, dentro de uma nova perspectiva, são equiparados, 
ao lado das regras, a espécie do gênero "norma" (PEREIRA, 2007).

Optou-se, pois, por uma retomada teórica breve do Princípio do Devido Processo Legal e o do Acesso à Justiça, compreendidos à luz do Fundamento da República do Brasil e Princípio da Dignidade da Pessoa Humana.

O Devido Processo Legal, Due Processo of Law, prestigiado no art. 5 , LIV, da CF/88, estabelece um rol de garantias fundamentais do Estado Democrático de Direito brasileiro. $\mathrm{O}$ dispositivo resguarda a igualdade entre as partes até o desfecho do conflito, através, por exemplo, da fundamentação de decisões, predeterminação do procedimento e regras de suspeição e impedimento, com vista à imparcialidade do julgador (PEREIRA, 2007).

No que concerne ao Acesso à Justiça, a previsão normativa ocorre no inciso XXXV do também art. $5^{\circ}$ da CF/88. O direito de ação poderá ser exercido, tendo razão ou não a parte, pelo fato de não ser possível determinar, de antemão, a parte merecedora da atuação estatal. Porém, além do simples ingresso ao Poder Judiciário, imperiosa é a reflexão sobre a qualidade das decisões proferidas na preservação do bem jurídico litigado. A preocupação com a efetividade dos provimentos jurisdicionais desponta na doutrina sob o nome de princípio da Efetividade (PEREIRA, 2007).

Segundo Pereira (2007), o Princípio da Instrumentalidade das Formas, expresso no art. 244 do CPC, repudia procedimentos alongados. A adoção da instrumentalidade, corolária da efetividade, aspira à celeridade aos atos processuais, conforme disposição do inciso LXXVIII do art. $5^{\circ}$ da CF/88, acrescido via Emenda Constitucional $\mathrm{n}^{\circ} 45$, que prevê o direito à razoável duração do processo.

A nova orientação do Direito de Família, por fim, leva a crer que a aplicação de todos os princípios deve ser associada ao Princípio da Dignidade da Pessoa Humana, concebido como superprincípio constitucional, orientador das relações jurídicas 
modernas. O Direito Processual não se pode furtar da aplicação desse Princípio. O patrimônio é relegado à condição de "suporte" para a integridade da pessoa. Destarte, inseparáveis os conceitos de devido processo legal, efetividade e razoável duração do processo (BRITO, 2006).

As delongas procedimentais podem culminar em condições de indignidade humana àquele que necessita de alimentos. Se o Estatuto cria normas que priorizam os feitos em benefício do idoso, com base no Princípio da Proteção Integral, não surpreende que maior urgência ainda deva ser atribuída às demandas sobre verbas de caráter alimentar.

Como se pretendeu demonstrar nas seções anteriores, a Lei 10.741 está comprometida com o efetivo cumprimento da obrigação. Parece ter sido esta a motivação da regra da solidariedade passiva do seu art. 12. Conjugados vínculo de parentesco e dever legal, ampliam-se as possibilidades de satisfação da prestação com mais agilidade, mediante a responsabilização de apenas um devedor, sabidamente capaz de efetuar o pagamento, ou de todos os demais conjuntamente.

O idoso, em situação de risco, não pode suportar os contratempos de um processo conturbado, especialmente se os acionados lançarem mão de todos os expedientes consagrados nas normas processuais como fim de procrastinar o exame definitivo da questão.

Sobre a intervenção de terceiros, deve adequar-se às especificidades do idoso, que não poderá aguardar excessivamente pela inclusão dos co-devedores no polo passivo. Dias (2007) já defendia que, apesar de solidária porque assim quis o legislador, a obrigação consubstanciada no Estatuto do Idoso não se adéqua a todas as regras previamente delineadas para o instituto. $\mathrm{Na}$ adoção desse posicionamento, a utilização do Princípio da Instrumentalidade das Formas e da Efetividade teria lugar privilegiado.

Afastada a regra da solidariedade, restaria apenas a aplicação do art. 1.698 do Código Civil. Inútil teria sido o esforço 
do legislador para atender justamente a efetividade do processo. O que o Estatuto pretende é possibilitar o acionamento de todos os co-obrigados de uma só vez, até para que, sendo viável, aplique-se também o Princípio da Economia Processual, ou mesmo de um só deles, pondo termo à demanda.

Se o processo é compreendido como um meio para que as normas de direito material sejam observadas e os bens jurídicos devidamente tutelados - e, quanto a isso, não restam dúvidas, uma vez que o ordenamento desfere proteção específica e integral ao idoso nos planos constitucional e infraconstitucional não se pode desperdiçar o intuito específico do legislador. $\mathrm{O}$ caso do idoso é especial, deve prevalecer a lei especial.

Se a processualística, nos moldes apresentados até o momento, é insuficiente, que se criem novas formas de assegurar a efetividade da regra alimentar; que o julgador aplique o Princípio da Proteção na hipótese de o réu pretender utilizarse do chamamento ao processo, impedindo de fazê-lo. Que se lhe determine intentar nova ação (de regresso) para que não se retarde o recebimento da prestação devida.

Uma regra não é esdrúxula porque foge à diuturnidade. Se assim o fosse, os institutos, inclusive processuais, não seriam revisitados constantemente. Todas as iniciativas rumo à celeridade seriam, assim, consideradas esdrúxulas. As próprias relações familiares, tal qual delineadas, seriam-na a olhos mais conservadores.

Se as inovações servem à consolidação da isonomia e da observância de demais regramentos constitucionais - especialmente do Princípio da Dignidade da Pessoa Humana - o Direito Processual deve festejar por auxiliar no fortalecimento do Estado Democrático de Direito. Quem sabe o papel conferido aos Princípios outrora, de coadjuvantes, seja outorgado à forma do Direito Processual, pois o Devido Processo Legal também é constituído de um aspecto substancial (Substantive Process of Law), além da procedimentalidade pura e simples. 
A interpretação da CF/88 não se pode dissociar do ideal sublinhado no processo de positivação dos Direitos Fundamentais, sob pena perderem o sentido. A Teoria das Gerações de Direitos vem fortalecer a compreensão de que o Estado tem, na proteção efetiva do cidadão, seu objetivo primordial, pois os bens jurídicos atrelados à dignidade da pessoa humana passam a ser tutelados com maior ênfase à cada geração, ou dimensão.

Conforme se buscou demonstrar, os subsídios constitucionais não são neutros. Resultam da nova tendência de produzir normas em benefício de contingentes hipossuficientes. Os sujeitos passam a ser tutelados em categorias, numa pluralidade de partes, de maneira transindividual. O envelhecimento passa a ser vislumbrado, pois, como um bem difuso, cuja preservação é imputada à família, ao Estado e à toda sociedade. Eis o fundamento para a reunião de esforços contundentes do legislador com vista à sua proteção integral do idoso, desde a promulgação da Constituição Federal até a promulgação da Lei 10.741 de 2003.

Nestes termos, os operadores do sistema jurídico necessitam de grande sensibilidade na procedimentalização das demandas alimentares. Devem, no caso concreto, amparados nos ideais sublinhados na Norma Maior, prestigiar a inovação legislativa do Estatuto.

\section{CONCLUSÃo}

Apesar de a obrigação alimentar não ser, na sua essência, solidária, como defenderam os autores colacionados, em razão da divisibilidade e da utilização de critérios de proporcionalidade para delimitar o débito, de acordo com o que a doutrina e a jurisprudência denominam binômio "necessidade-possibilidade", a regra em favor do idoso fez merecer mais aprofundamento.

Na observância do art. 265 do CC, a Lei 10.741/03 adequou a solidariedade passiva da obrigação alimentar ao sistema brasileiro porque não a fez presumir. Demonstrou preocupação com a celeridade do cumprimento da obrigação, pois 
facultou ao idoso o direito de exigi-lo da integralidade de devedores ou de quaisquer deles simultaneamente.

Sob o aspecto formal, a norma é valida, pois não the incide vício de quorum ou iniciativa. Ainda que o art. 11 do Estatuto preceitue que os alimentos serão prestados na forma da lei civil, devem ser afastadas as disposições conflitantes com o próprio Estatuto ante a preponderância da norma especial (RIZZARDO, 2008).

Desta forma, compartilha-se do entendimento de Rizzardo (2008) e Dias (2007) no sentido de acatar a solidariedade da obrigação alimentar do idoso, com fundamento na textualidade do dispositivo e em atenção ao Princípio da Proteção Integral, que permeia o Estatuto. Ainda que a priori incompatível com a regra da possibilidade do alimentante, o que se destaca é a faculdade de acionar apenas um dos devedores com vista à satisfação célere da prestação, o que não exclui ulterior ressarcimento em relação aos co-devedores. De fato, eis a maior herança do microssistema: proteção específica às necessidades especiais do público idoso, consonantes com um Estado Democrático de Direito.

Nada deve obstar o cumprimento da Lei Maior, responsável por consolidar Direitos Fundamentais conquistados historicamente, por etapas. A proteção desferida pela CF/88 ao idoso é contundente, pois assegura proteção ao indivíduo isolado e ao segmento por inteiro, dentro da noção de direitos transindividuais, especialmente difusos. A família, o Estado e a Sociedade Civil estão obrigados moral e formalmente com o idoso, não apenas no tocante a alimentos, mas também no que se refere à sua integração, ao convívio social e ao exercício pleno de sua cidadania, indissociável do preceito da dignidade.

Abstract: This article aims at investigating the true nature of the nutritive obligation in favor of the elderly concerning the attribute of passive solidarity in the face of the contradictions between the doctrine of obligatory law and family law in relation to the statute of the Elderly in this regard. 
Key Words: passive solidarity. nutritive obligation. the elderly statute

\section{REFERÊNCIAS}

BOBBIO, Norberto. A Era dos Direitos. 4a ed. Rio de Janeiro: Elsevier, 2004.

BRASIL. Código Civil (2002). Disponível em <www.presidencia.gov.br>.

BRASIL. Constituição (1988). Constituição da República Federativa do Brasil. Brasília. Senado Federal. 1988.

BRASIL. Lei no 8742, de 9 de dezembro de 1993. Dispõe sobre a organização da Assistência Social e dá outras providências. Disponível em <www.presidencia.gov.br>. Legislação Federal.

BRASIL. Lei no 8842, de 4 de janeiro de 1994. Dispõe sobre a política nacional do idoso, cria o Conselho Nacional do Idoso e dá outras providências. Disponível em <www.presidencia.gov.br〉. Legislação Federal.

BRASIL. Lei no 10741 , de $1^{\circ}$ de outubro de 2003. Dispõe sobre o Estatuto do Idoso e dá outras providências. Legislação Federal. Disponível em <www.presidencia.gov.br>.

BRASIL, Supremo Tribunal Federal. Constitucional. Impugna dispositivo de lei federal que estabelece o critério para receber o benefício do inciso $\mathrm{V}$ do art. 203 da CF. Inexiste a restrição alegada em face ao próprio dispositivo constitucional que reporta à lei para fixar os critérios de garantia do benefício de salário mínimo à pessoa portadora de deficiência física e ao idoso. Esta lei traz hipótese objetiva de prestação assistencial do Estado. Ação julgada improcedente. Acórdão em Ação Direta de Inconstitucionalidade n. ${ }^{\circ}$ 1.232-1. Rel. Min. Ilmar Galvão. DJ 01.06.2001, disponível em <www.stf.jus.br>. Acesso em 22/6/2010.

BRITO de, Rodrigo Azevedo Toscano. Situando o Direito de Família entre os princípios da dignidade humana e da razoável duração do processo. In Rodrigo da Cunha Pereira. São Paulo: IOB Thompson, 2006. Família e dignidade humana/V Congresso Brasileiro de Direito de Família.

DELGADO, Mário Luiz. Direitos da personalidade nas relações de família. In Rodrigo da Cunha Pereira. São Paulo: IOB Thompson, 2006. Família e dignidade humana/V Congresso Brasileiro de Direito de Família. 
DIAS, Maria Berenice. Manual de Direito das Famílias. 4 ed. São Paulo: Editora Revista dos Tribunais, 2007.

DIDIER, Fredie Jr. Curso de Direito Processual Civil. Teoria Geral do Processo e Processo de Conhecimento. 11 ${ }^{\text {a }}$ Ed. São Paulo: Editora Jus Podivm. 2009.

GAMA da, Guilherme Calmon Nogueira. Direito Civil: obrigações. São Paulo: Atlas. 2008.

GROENINGA, Giselle Câmara. O direito à integridade psíquica e o livre desenvolvimento da personalidade In Rodrigo da Cunha Pereira. São Paulo: IOB Thompson, 2006. Família e dignidade humana/ V Congresso Brasileiro de Direito de Família.

INDALENCIO, Maristela Nascimento. O termo de acordo extrajudicial de alimentos em prol da pessoa idosa, seu referendo pelo Ministério Público e aspectos de sua executividade: a possibilidade da prisão civil. In Revista Brasileira de Direito das Famílias e Sucessões. n 5. Ago-Set, 2008.

MAZZILLI, Hugo Nigro. A Defesa dos Interesses Difusos em Juizo: meio ambiente, consumidor e outros interesses difusos e coletivos. 14 ed. São Paulo: Saraiva, 2002.

PAULO, Vicente. Aulas de Direito Constitucional. 8 ed. Rio de Janeiro: Impetus, 2006.

PONTES, Patrícia Albino Galvão. In Estatuto do Idoso Comentado. 2 ed. Org. Naide Maria Pinheiro. Campinas: Servanda, 2008. p. 247-254.

PEREIRA, Hélio do Vale. Manual de Direito Processual Civil: Roteiros de aula - Processo de Conhecimento. Florianópolis: Conceito Editorial, 2007.

RIZZARDO, Arnaldo. Direito de Família. 6 ed. Rio de Janeiro: Forense, 2008,

WAMBIER, Luiz Rodrigues (coord); TALAMINI, Eduardo; ALMEIDA de, Flávio Renato Correia. Curso avançado de processo civil: teoria geral do processo e processo de conhecimento. 10a ed. São Paulo: Editora Revista dos Tribunais, 2008.

WOLKMER, Antônio C. LEITE, José Rubens M. (Org) Os "Novos Direitos no Brasil: natureza e perspectiva: Uma Visão Básica das Novas Conflituosidades Jurídicas. São Paulo: Saraiva, 2003. 